\title{
Additions to the Check-list of Saskatchewan Birds
}

\author{
by R. W. Nero and C. S. Houston
}

The last full listing of Saskatchewan birds was that of the fourth edition of the Field Cherk-list (Houston, Nero, and Bard, 1959). That list included 309 species definitely identified (not 308 as given), plus 11 species whose status was hypothetical (not 12 as given). In recent years some additional information has becone available necessitating a change in status for some species and the addition of a few new species. Two species which were formerly listed as hypothetical may be given full status: Poor-will and Cardinal. Nine species may be added to the list for the first time. Of these, five have full status: Greater Scaup, Rock Ptarmigan, Glaucous Gull, Iceland Gull, and Little Gull; four are hypothetical: Eskimo Curlew, Longtailed Jaeger, Least Tern, and Golden-winged Warbler. Two additional species, American Woodcock and House Finch, have been mentioned in the literature, but we have not thought the records substantial enough to warrant adding these species to the list. This brings the list of Saskatchewan birds to 316 species which have been definitely identified, plus 13 others classed as hypotheticals.

GREATER SCAUP. Aythya marila (Linnaeus). Rare transient. Recently recorded as hypothetical on the basis of sight records by O. C. Furniss at Prince Albert in April, 1935 (Houston and Street, 1959). Given full status following examination of a female taken at Indian Head, Saskatchewan, by Wm. Spreadborough in 1892 and now in the Museum at Banff (Godfrey, 1962).

ROCK PTARMIGAN. Lagcpus mutus (Montin). Rare winter visitant in the extreme north. Two specimens from Uranium City, north shore of Lake Athabasca, collected by E. Otto and A. Scarfe, are in the Saskatchewan Museum of Natural History (Nero, 1963).

[AMERICAN WOODCOCK. Philohela minor (Gmelin). A sight record reported by Tyrrell on the Fond du Lac River in 1892 is the basis for including this species as a hypothetical on the Lake Athabasca list (Nero, 1963). However, both this record and a dubious record by Harrison (1960) in the Qu'Appelle Valley east of Craven are considered doubtful by us and the species is not admitted to the provincial list. I

(ESKIMO CURLEW). Numenius borealis (Forster). Hypothetical. Given hypothetical status on the basis of apparent sight records, without details, by Richardson in the 1820's. Although some recent sight records in the southern United States have been generally accepted (A.O.U., 1963), it is unlikely that we will ever be able to establish this species as a bona fide visitor to Saskatchewan.

(LONG-TAILED JAEGER). Stercorarius longicaudus Viellot. Hypothetical. Sight records at Kazan Lake, June 13, 1942 (Randall, 1962), and at Black Bày, Lake Athabasca, July 25, 1962 (Nero, 1963), have added this species, which is not easily identified with certainty in the field, to our hypothetical list.

GLAUCOUS GULL. Larus hyperboreus Gunnerus. Rare visitant in the extreme north. One was collected near Beaverlodge Lake, north shore of Lake Athabasca, June 13, 1960, following a sight record on May 25, 1960 (Nero, 1963).

ICELAND GULL. Larus glaucoides Meyer. Uncommon summer visitant in the extreme north. A controversial form, this gull is variously considered a subspecies of the Herring Gull, or a distinct species known as Thayer's Gull. Most recently it has been designated a subspecies of the Iceland Gull (Macpherson, 1961). Eight of these gulls were seen and some were photographed in color on June 5, 1960, near Beaverlodge Lake, and an immature male was collected on July 9, 1960 (Nero, 1963).

LITTLE GULL. Larus minutus Pallas. Rare visitant in the extreme north. The A.O.U. Check-list (1957) lists this species for Saskatchewan on the basis of the specimen collected by Richardson during the first Franklin expedition of 1819-1822. However, Houston and Street (1959) 
have shown that the geographic origin of this specimen is uncertain, and they listed the species as hypothetical. Full status was attained in 1962 when one was collected on June 28, 1962, at Little Gull Lake, just south of Lake Athabasca (Nero, 1963).

(LEAST TERN). Sterna albifrons Pallas. Hypothetical, A sight observation at Regina on May 26, 1957 (Brazier, 1960), was apparently rejected by Belcher (1961). Recent records in central North Dakota (pers. corres., Robert E. Stewart, 1963) suggest that a specimen may some day be collected in Saskatchewan.

POOR-WILL. Phalaenoptilus nuttalli (Audubon). Accidental in the south (south end of Last Mountain Lake) and a rare, though apparently regular, late summer visitant in the Cypress Hills. Previously on the hypothetical list on the basis of two sight records (Mitchell, 1924). Several were seen and a specimen was collected by Bruce A. McCorquodale and Albert E. Swanston at Calf Creek, 12 miles northwest of Eastend, on August 22, 1961 (Bard, 1961). (GOLDEN-WINGED WARBLER). Vervimora chrysoptera (Linnaeus). Hypothetical status for this new visior is based on a carefully documented sight record at Regina, May 18, 1962 (Brazier, 1962).

CARDINAL. Richmondena cardinhlis (Linnaeus). Rare visitant in the outh, with several sight records as ar north as Saskatoon. Placed on the full list when one was collected it Craven, December 29, 1960 (Fox, (961).

[HOUSE FINCH. Carpodacus mexifanus (Müller). A possible sight reord for this species at Saskatoon in nid-October, 1959 (Saunders, 1959) s not fully acceptable since one mportant field mark was not reorded: According to the A.O.U. Check-list (1957) it breeds to southNestern Alberta and central Monana, and stragglers might be expected in Saskatchewan.I

\section{LITERATURE CITED}

merican Ornithologists' Union. 1957. Checklist of North American birds. Fifth ed., $691 \mathrm{pp}$.

O.U. Report to the American Ornithologists' Union by the Committee on Bird Protection. 1963, Auk, 80:352-364.

ard, F. G. 1961. First Poor-will specimen for Saskatchewan taken. Blue Jay, 19:172.
Belcher, M. 1961. Birds of Regina. Special Publ. No. 3, Sask. Nat. Hist. Soc., Regina, Saskatchewan. 76 pp.

Brazier, F. 1960. A possible Least Tern in Saskatchewan. Blue Jay, 18:162.

Brazier, F. 1962. A Golden-winged Warbler in Regina. Blue Jay, 20:153-154.

Fox, E. L. 1961. First Cardinal specimen for Saskatchewan. Blue Jay, 19:77-79.

Godfrey, W. E. 1962. A Saskatchewan specimen of the Greater Scaup. Can. Field-Nat., 76:125.

Harrison, S. 1960. Woodcock sighted in the Qu'Appelle Valley. Blue Jay, 18:160.

Houston [C.] S., F. G. Bard, and R. W. Nero 1959. Field Check-list of Saskatchewan birds. Fourth edition, revised June, 1959. Sask. Museum of Nat. History, Regina.

Houston, C. S., and M. G. Street. 1959. The birds of the Saskatchewan River, Carlton to Cumberland. Special Publ. No. 2, Sask. Nat. Hist. Soc., Regina, Sask. 205 pp.

Macpherson, A. H. 1961. Observations of Canadian Arctic Larus gulls, and on the taxonomy of L. thayeri Brooks. Arctic Inst. of $N$. Amer., Tech. Paper No. 7, 40 pp.

Mitchell, H. H. 1924. Birds of Saskatchewan. Can. Field-Nat., 38(6):101-118.

Nero, R. W. 1963. Birds of the Lake Athabasca region, Saskatchewan. Special Publ. No. 5, Sask. Nat. Hist. Soc., Regina, Sask. 143 pp. 112 plates.

Randall, T. E. 1962. Birds of the Kazan Lake region, Saskatchewan. Blue Jay, 20:60-72. Saunders, L. G. 1959. Birds in an apple tree. Blue Jay, 17:158.

\section{GREATER SCAUP SIGHTED IN REGINA}

\section{by Douglas E. Wade and Dorothy} R. Wade, Regina

On October 23, 1963, the writers in company with their son, visited the Regina Waterfowl Park (Wascana Marsh) between $4: 30$ and 6 p.m. looking for a Black Duck which had been reported by Fred Lahrman. While systematically searching the marsh for the Black Duck (which we did not see), we saw a male scaup duck about 20 yards from our car and in excellent light. During the few seconds the scaup remained on the water, it appeared to be different from the Lesser Scaup of which we had just seen several. It was larger in size and its head was rounder. It took flight away from us on such an angle and in such good light that the wing pattern was most clearly disoernible and the white striping on the wing showed itself extending almost the entire length of the wing. The duck was observed through binoculars during flight for about 200 yards. We are both familiar with the Greater and the Lesser Scaup, having had many opportunities to observe the former while we resided in eastern North America, from the New England coast to South Carolina. 